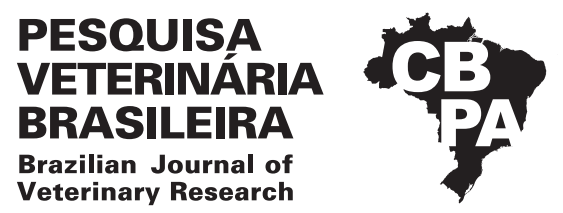

Pesq. Vet. Bras. 38(8):1459-1470, agosto 2018 DOI: $10.1590 / 1678-5150-P V B-5795$

Review Article

Animais de Produção/Livestock Diseases

ISSN 0100-736X (Print)

ISSN 1678-5150 (Online)

\title{
Poisoning of cattle by Senecio spp. in Brazil: a review ${ }^{1}$
}

\author{
Welden Panziera², Saulo P. Pavarini' ${ }^{2}$, Luciana Sonne ${ }^{2}$, Claudio S.L. Barros ${ }^{3}$ \\ and David Driemeier ${ }^{2 *}$
}

\begin{abstract}
Panziera W., Pavarini S.P., Sonne L., Barros C.S.L. \& Driemeier D. 2018. Poisoning of cattle by Senecio spp. in Brazil: a review. Pesquisa Veterinária Brasileira 38(8):1459-1470. Setor de Patologia Veterinária, Faculdade de Veterinária, Universidade Federal do Rio Grande do Sul, Av. Bento Gonçalves 9090, Prédio 42505, Porto Alegre, RS 91540-000, Brazil. E-mail: davetpat@ufrgs.br

Poisoning of cattle by plants of the Senecio genus represents an important cause of death in cattle and has important economic repercussions in southern Brazil. This review is intended to provide a detailed review of Senecio spp. intoxication in cattle and addresses issues regarding the toxic principle and pathogenesis of the disease caused by these plants and the epidemiology, clinical signs, diagnosis, control and prophylaxis of the disease. Senecio brasiliensis is the main species associated with natural intoxication of livestock in Brazil, and the number of cases associated with the ingestion of $S$. madagascariensis is increasing. The toxic principle of Senecio spp. comprises the hepatotoxic alkaloids of the pyrrolizidine group (pyrrolizidine alkaloids, PAs). The resulting liver lesions are chronic and irreversible and result from the inhibition of hepatocellular mitosis. Deaths of adult cattle may occur both sporadically and in larger outbreaks over an extended period of time. In cattle raising, Senecio spp. are consumed mainly during the winter, when there is a dearth of forage; at this time the poisonous Senecio species are budding and contain high concentrations of PAs. Spontaneous Senecio spp. intoxication in cattle is a chronic condition that frequently involves acute clinical manifestations. Affected cattle may present ascites, emaciation, intermittent dark diarrhea, tenesmus, rectal prolapse, and neurological signs resulting from hepatic encephalopathy. Hepatogenous photosensitization may be observed but is uncommon. Necropsy findings include dependent subcutaneous edema, ascites, and edema of the mesentery, abomasal folds, and gallbladder. The liver is firm, normal or reduced in size with a white, thick capsule. Microscopically, the hallmarks of Senecio-associated disease are varying degrees of hepatocellular megalocytosis, bile duct hyperplasia and fibrosis. Sheep are significantly more resistant to Senecio intoxication than are cattle and avidly ingest Senecio plants; therefore, the use of sheep for grazing infested pasture is recommended for preventing the associated disease in cattle.
\end{abstract}

INDEX TERMS: Poisonous plants, Senecio spp., Brazil, diseases of cattle, intoxications, diseases of the liver, plant poisoning, cattle, sheep, toxicoses.

RESUMO.- [Intoxicação por Senecio spp. em bovinos no Brasil: revisão de literatura.] Intoxicação por plantas do gênero Senecio representa uma importante causa de morte

\footnotetext{
${ }^{1}$ Received on February 2, 2018.

Accepted for publication on February 9, 2018.

${ }^{2}$ Setor de Patologia Veterinária, Departamento de Patologia Clínica Veterinária, Faculdade de Veterinária, Universidade Federal do Rio Grande do Sul (UFRGS), Av. Bento Gonçalves 9090, prédio 42505, Porto Alegre, RS 91540-000, Brazil. *Corresponding author: davetpat@ufrgs.br

${ }^{3}$ Laboratório de Anatomia Patológica, Faculdade de Medicina Veterinária e Zootecnia, Universidade Federal de Mato Grosso do Sul (UFMS), Av. Senador Filinto Müller 2443, Campo Grande, MS 79074-460, Brazil.
}

em bovinos com grande repercussão econômica na região sul do Brasil. 0 objetivo dessa revisão é fornecer uma abordagem detalhada da intoxicação por Senecio spp. em bovinos, com enfoque nos seguintes aspectos da intoxicação: princípio tóxico e patogenia, epidemiologia, sinais clínicos, diagnóstico e controle e profilaxia. Senecio brasiliensis constitui a principal espécie associada a intoxicações espontâneas em animais de produção e há uma crescente incidência de casos relacionados à intoxicação por S. madagascariensis. A toxicidade das espécies de Senecio deve-se à presença de alcaloides hepatotóxicos pertencentes ao grupo das pirrolizidinas (APs), que produzem lesão hepática crônica e irreversível, caracterizada pela 
inibição da mitose de hepatócitos. As mortes dos bovinos adultos acontecem de forma esporádica ou em surtos durante um período prolongado de tempo, e podem ocorrer durante o ano todo. As espécies do gênero Senecio são pouco palatáveis e consumidas pelos bovinos somente em determinadas circunstâncias, principalmente, no inverno, período em que as diferentes espécies estão em brotação, com maior concentração de alcaloides, e a disponibilidade de forragem é escassa. A intoxicação geralmente cursa com um quadro crônico, embora as manifestações clínicas sejam agudas. Os bovinos afetados podem apresentar ascite, emagrecimento, diarreia escura intermitente, tenesmo, prolapso retal e sinais neurológicos (encefalopatia hepática). Ocasionalmente ocorre fotossensibilização hepatógena. Na necropsia, os principais achados incluem edema subcutâneo ventral, ascite, edema de mesentério e das pregas do abomaso, distensão e edema da vesícula biliar e fígado firme, diminuído de tamanho e com a cápsula brancacenta. Microscopicamente, as principais alterações hepáticas consistem de graus variados de hepatomegalocitose, hiperplasia de ductos biliares e fibrose. A profilaxia inclui o uso de ovinos para pastorear os campos infestados pela planta, visto que essa espécie é mais resistente à ação dos APs e apresenta avidez no consumo da brotação da planta.

TERMOS DE INDEXAÇÃO: plantas tóxicas, Senecio spp., Brasil, doenças de bovinos, intoxicações, doenças do fígado, intoxicação por plantas, bovinos, ovinos, toxicoses.

\section{INTRODUCTION}

Worldwide, over 1,200 Senecio (Asteraceae) species have been described, of which approximately 25 have been found to be toxic to domestic animals or human beings (Tokarnia et al. 2012). Depending on the source of information, there are between 90 (Cabrera 1957) and 128 (Motidome \& Ferreira 1966) Senecio species in Brazil. Among them, nine have been reported as toxic to cattle: Senecio brasiliensis (Tokarnia \& Döbereiner 1984, Méndez et al. 1990, Driemeier et al. 1991, Barros et al. 2007), S. cisplatinus, S. heterotrichius, S. selloi (Méndez et al. 1990), S. oxyphyllus (Barros et al. 1987a, Barros et al. 1992, Driemeier \& Barros 1992), S. madagascariensis (Cruz et al. 2010, Stigger et al. 2014), S. tweediei (Méndez \& Riet-Correa 1993) and S. desiderabilis (Tokarnia et al. 1990). The toxicity of latter was demonstrated only experimentally.

It is well established that Senecio spp. are the most important toxic plants affecting cattle in southern Brazil (Driemeier et al. 1991, Barros et al. 1992). They are responsible for more than $50 \%$ of all cattle deaths caused by poisonous plants in the state of Rio Grande do Sul, Southern Brazil (Riet-Correa \& Medeiros 2001, Karam et al. 2004, Rissi et al. 2007).

Intoxication with plants of the Senecio genus is also important in other countries of South America (Uruguay, Argentina, and Paraguay), North America, Europe, South Africa, Australia, and New Zealand (Kellerman et al. 2005, Molyneux et al. 2011, McKenzie 2012). In South Africa, approximately 250 Senecio species have been identified, among which $S$. latifolius and S. retrorsus are the most important (Kellerman et al. 2005). Worldwide, other Senecio species related to intoxication in livestock include S. jacobaea, S. plattensis and S. vulgaris in North America and S. brigalowensis and S. linearifolius in Australia and New Zealand (Coombs et al. 1991, McEvoy et al. 1991, Kellerman et al. 2005, Molyneux et al. 2011, McKenzie 2012).
The list of identified toxic species is increasing; recently, S. grisebachii was found to be toxic to cattle in Uruguay (Preliasco et al. 2017).

In light of the great importance of Senecio spp. poisoning in cattle in southern Brazil and the great economic impacts of the disease, this review aims to provide a detailed overview of several aspects of intoxication, namely, the toxic principle, pathogenesis, epidemiology, clinical signs, diagnosis, control, and prophylaxis.

\section{MORPHOLOGICAL CHARACTERISTICS OF Senecio brasiliensis AND Senecio madagascariensis}

We present here the characteristics of the most common species of Senecio in the country (S. brasiliensis) and one of steadily growing importance ( $S$. madagascariensis) as representatives of the genus.

S. brasiliensis is the most widely distributed species in Brazil and is responsible for the great majority of cases of spontaneous intoxication in cattle. It is a native weed in South America and widely distributed in the southern region of Brazil. Occasionally, it is observed in high and cold areas of the southeastern region of the country. Elsewhere in South America, S. brasiliensis is most frequently found in Uruguay, Argentina and Paraguay (Kissmann \& Groth 2000, Lorenzi 2008, Matos et al. 2011). Colloquially, the plant is known mainly as "flor das almas" (Portuguese for "flower for the souls")". The adult plant of $S$. brasiliensis is a perennial, erect bush, propagated by seeds; its height is $0.80-1.60 \mathrm{~m}$. The leaves are alternate, oblong-deltoid, pinnatifid, sessile, approximately $12 \mathrm{~cm}$ in length, and divided into 5-11 complete and linear segments. The flowers are yellow and gathered in dense paniculate corymbous chapters. The fruit is cylindrical, glabrous and dark colored (Kissmann \& Groth 2000, Lorenzi 2008) (Fig.1A-C).

In addition to the many cases of $S$. brasiliensis, cases of natural intoxication caused by $S$. madagascariensis have been increasing in southern Brazil (Cruz et al. 2010, Stigger et al. 2014). This plant is native to Madagascar and South Africa. It is an important invasive weed, especially in latitudes similar to those of its origin (Scott et al. 1998). It has been introduced accidentally in several countries, including Australia (McKenzie 2012), the United States (Roux et al. 2006), Argentina (Villalba \& Fernández 2005), Uruguay, Japan (Tsutsumi 2011) and Brazil (Cruz et al. 2010). It was originally identified in the state of Rio Grande do Sul in 1995 (Matzenbacher \& Schneider 2008). This species has great dispersal capacity and exhibits high levels of environmental and climatic adaptation due to its hibernal characteristics (Matzenbacher \& Schneider 2008). S. madagascarienis is an upright perennial herb $20-60 \mathrm{~cm}$ in height, hairless or sparsely hairy, occasionally with numerous branching stems. Leaves are alternate in the midregion of the stems; they are mostly simple, $3-10 \mathrm{~cm}$ in length, and narrow, with 15-25 tiny teeth (denticulations) along the edges. The few divided leaves have one or two narrow-triangular lobes that lie approximately centrally on each side. Groups of two to 20 bright yellow daisy-type flower heads occur at the top of the stem branches. Each flower head has approximately 20 involucral bracts with brown or black tips in an involucre of 4-6mm in length and approximately 3-5mm in diameter. There are 50-70 florets, approximately 13-15 of which are 




Fig.1. Characteristics of Senecio brasiliensis and S. madagascariensis. (A) Pasture in the fall intensely invaded by blooming S. brasiliensis. (B) Closer view of $S$. brasiliensis specimens; the petals of the flowers are characteristic yellow. (C) A sprouting S. brasiliensis specimen during winter can be observed here. At this stage, the weed is more easily ingested by cattle. (D) Pasture in the fall intensely invaded by blooming S. madagascariensis; the plant is shorter than S. brasiliensis. (E) Closer view of a flowering S. madagascariensis specimen. (F) Both flowering and senescence (white heads) phases of $S$. madagascariensis can be observed here.

florets with petals 5-10 $\mathrm{mm}$ in length. Seeds are mid-to-dark in color, $1.5-2.5 \mathrm{~mm}$ in length, with pappus bristles $3-6.5 \mathrm{~mm}$ in length (McKenzie 2012) (Fig.1D-F).

\section{TOXIC PRINCIPLE AND PATHOGENESIS}

The toxic principle of plants of the genus Senecio comprises pyrrolizidine alkaloids (PAs). PAs are naturally occurring phytochemicals in approximately 6,000 plant species of different genera and families (Lucena et al. 2010). In addition to occurring in the genus Senecio, PAs are present in other plants, mainly of the genera Echium, Crotalaria and Heliotropium (Kellerman et al. 2005). Toxicity is of great importance in livestock, and although rare, there are reports of intoxication in humans, primarily in underdeveloped countries and related to eating habits (McLean 1970, Molyneux et al. 2011). PAs cause irreversible damage to the liver and have a potential 
carcinogenic effect (McLean 1970). The PAs contained in the plants are not chemically reactive, and most of them are excreted unchanged. However, they become toxic when they biotransform in the liver into a highly reactive pyrrole, known as 1,2-dehydropyrrolizidine, which is the primary toxic metabolite. Secondary toxic metabolites, termed alcoholic pyrroles, are also formed (McLean 1970, Prakash et al. 1999).

The biosynthesis of PAs begins at the roots of the plant, where N-oxides are produced. PAs are then transported to higher plant structures, namely, the leaves and flowers. There they undergo molecular changes, resulting in different PAs. However, they only become toxic when they are metabolized by the liver into a highly reactive pyrrole (Silva et al. 2006), as previously described. A number of PAs have been extracted from $S$. brasiliensis, including integerrimine, senecionine, retrorsin, and usuramine (McLean 1970, Hirschmann et al. 1987, Silva et al. 2006, Matos et al. 2011, Molyneux et al. 2011, Pavarini et al. 2012). Alkaloids identified in other species of Senecio include the following: neosenkirkina, integerrimina and florosenina in S. leptolobus; retrorsin, senecionin, 18-hydroxy-jaconin and senecivernin in S. selloi; retrorsin and senecionine in S. cisplatinus; retrorsin and integerrimine in S. heterotrichius; and retrorsin and ligularizine in S. oxyphyllus (Méndez et al. 1990, Liddell et al. 1992, Krebs et al. 1996, Pavarini et al. 2012, Tokarnia et al. 2012). The accumulation of pyrrolizidine alkaloids might be related to the seasonality and phenology of Senecio species (Karam et al. 2002).

Chemically, PAs are heterocyclic molecules that contain a nitrogen atom attached to the main ring and are generally alkaline substances. The basic nucleus of an aminoalcohol is termed a necine (pyrrolizidine nucleus), consisting of two rings of five atoms joined by a single nitrogen atom; the acidic portion is termed a necic acid (aliphatic acid) and is composed of one or two branches of a carboxylic ester (McLean 1970, Molyneux et al. 2011, Pavarini et al. 2012).

The basic structure responsible for the hepatotoxicity of PAs is determined by at least four structural characteristics (Prakash et al. 1999): (1) one 3-pyrroline ring, (2) one or two hydroxyl groups attached to the pyrroline ring, (3) one or two esterified groups, and (4) a branched chain on the acid residue. However, the essential characteristic underlying hepatic toxicity, both acute and chronic, is the unsaturated necine between carbons 1 and 2 (Sandini et al. 2013).

After absorption, PAs reach the liver via portal circulation and are biotransformed by the hepatic microsomal enzymes of the cytochrome P450 complex, yielding highly toxic pyrroles. The major routes of hepatic metabolism of PAs are ester hydrolysis, $\mathrm{N}$-oxidation, and dehydrogenation. The first two reactions are involved in the detoxification mechanism, whereas dehydrogenation is related to pyrrole formation. Pyrroles, responsible for toxicity (Santos et al. 2008), are electrophilic and react with nucleophilic tissue components, such as nucleic acids and proteins (Sperl et al. 1995). As the liver is the site of production of these toxic pyrroles, it is a major target organ, followed by the lungs (Sandini et al. 2013). Pyrroles injure hepatocytes, irreversibly binding to DNA (the alkylating effect) and inhibiting hepatocyte mitosis. As DNA continues to be synthesized in the nucleus, the nuclear and cytoplasmic volumes of the non-dividing cell continue to increase. This increase in the whole cell volume (not only the nucleus volume) is termed hepatomegalocytosis
(Bull 1955). Despite their volume, megalocytes are not higher functioning cells; their metabolism diminishes considerably (Seawright et al. 1991), and those attempting mitosis die (McLean 1970) and are replaced by connective fibrous tissue; these changes are referred to as hepatocyte loss and fibrosis, respectively. A portion of the pyrroles may escape into the general circulation (spillover effect), causing damage to other tissues, such as those of the kidney and lungs, as cytochrome P450 enzymes are also present in these organs (McLean 1970, Molyneux et al. 2011).

All parts of $S$. brasiliensis are toxic, as fresh or dried material (Tokarnia et al. 2012). However, some studies have shown variations in toxicity related to the time of year (seasonal variation), development stage (budding, flowering), and plant part (stems, roots, or seeds) (Johnson et al. 1985, Karam et al. 2002, Tokarnia et al. 2012, Sandini et al. 2013). The content of PAs in S. madagascariensis is highest in the aerial parts, especially the flowers during spring. The variety of PAs present and the variation in the content of each directly influence the toxic effect of the plant and consequently, the manifestation of disease (Karam et al. 2011).

The toxic dose can be highly variable depending on the plant species considered, the stage of growth, the content of alkaloids present, the period (duration) of ingestion, and idiosyncratic factors related to the animal itself (Karam et al. 2004). Acute intoxication with $S$. brasiliensis was reproduced with single doses corresponding to 17.5 and $35 \mathrm{~g} / \mathrm{kg} /$ body weight (bw) of green plant. The chronic manifestation of disease was observed with single doses of $5-10 \mathrm{~g} / \mathrm{kg} / \mathrm{bw}$ of fresh green plant or with repeated daily doses of $0.625-5 \mathrm{~g} / \mathrm{kg} / \mathrm{bw}$ totaling $75-150 \mathrm{~g} / \mathrm{kg} / \mathrm{bw}$. Chronic intoxication was also reproduced with weekly doses equivalent to the accumulation of seven daily doses of $2.18-8.75 \mathrm{~g} / \mathrm{kg} / \mathrm{bw}$, totaling $61.25-78.75 \mathrm{~g} / \mathrm{kg}$ for 1-8 months (Tokarnia \& Döbereiner 1984). Experiments with other Senecio species in cattle were lethal at total doses of $22.5 \mathrm{~g} / \mathrm{kg} / \mathrm{bw}$ (S. cisplatinus), $180 \mathrm{~g} / \mathrm{kg} / \mathrm{bw}$ (S. heterotrichius) and $45-180 \mathrm{~g} / \mathrm{kg}$ (S. selloi) of dried plant (Méndez et al. 1990).

\section{EPIDEMIOLOGY}

Several studies have demonstrated the sensitivity of cattle to Senecio intoxication and the high frequency of cases in cattle (Méndez et al. 1987, Driemeier et al. 1991, Barros et al. 1992, Basile et al. 2005, Barros et al. 2007, Pedroso et al. 2007, Rissi et al. 2007, Grecco et al. 2010, Lucena et al. 2010, Giaretta et al. 2014a, Panziera et al. 2017). Typically, spontaneous disease is observed in 2-year-old or older grazing cattle (Barros et al. 2007, Barros 2016). Occurrence in calves is uncommon (Basile et al. 2005, Barros et al. 2007, Panziera et al. 2017). However, it has been shown experimentally that young cattle are more susceptible to intoxication than are older cattle (Torres \& Coelho 2008). Occasionally, intoxication is associated with the consumption of hay that has been contaminated with the plant (Barros et al. 1987b, Basile et al. 2005, Barros et al. 2007, Barros 2016).

Most cases of poisoning occur in cattle that have undergone a period of forage deprivation during the year or the previous year. The risk of ingestion of Senecio spp. through direct grazing is higher in times of lack of forage dearth, as Senecio spp. are not palatable and are consumed by cattle only under certain conditions. It is estimated that Senecio spp. are ingested in greater amounts during the winter, from May to August. 
During this time, plant sprouting occurs, and there is a higher concentration of alkaloids in the weed. Furthermore, during this period, the availability of fodder is scarce in the native fields of Southern Brazil (Barros et al. 1987a, Driemeier et al. 1991, Barros et al. 1992, Riet-Correa \& Méndez 2007, Tokarnia et al. 2012). Cattle deaths may occur months or years after the last intake of the plant or after the plant has wilted and is no longer evident in the pasture (Barros 2016).

The overcrowding of cattle during the winter and the large number of sprouting weeds will predispose their ingestion, especially if the sprouts are in close association with forage grass (Driemeier et al. 1991, Barros et al. 1992). Although the intake frequency of Senecio spp. by cattle is higher from May to August (winter), ingestion and intoxication can occur outside this period. Under favorable environmental conditions for plant growth (precipitation, soil moisture, light, temperature, and pasture management in each property), sprouting may occur at any time of the year. Depending on the damage suffered, such as excessive trampling and cutting, Senecio spp. can behave as annual, bi-annual, or perennial species. If injury is intense or frequent, many Senecio spp. will exhibit a bi-annual cycle, with most plants needing two or more years to bloom. However, if conditions are consistently favorable for growth, some plants may flower during the first year, behaving as annuals (Karam et al. 2004, 2011). In Rio Grande do Sul, it has been observed that Senecio spp. in a vegetative stage are consistently present, indicating the constant exposure of livestock to the weed. Thus, cattle deaths can occur throughout the year (Karam et al. 2002, 2004, Riet-Correa \& Méndez 2007).

\section{CLINICAL SIGNS}

The clinical manifestations of Senecio spp. poisoning in cattle are secondary to chronic hepatic lesions (Barros 2016). Acute cases of the disease are rare in nature and are mostly restricted to experimental trials (Tokarnia et al. 2012). Repeated ingestion of small amounts of the sprouting plant over a prolonged period causes progressive hepatic injury over weeks or months until the disorder becomes sufficiently severe and signs of liver failure ensue. In such cases, cattle ingest quantities insufficient to induce the acute form. However, small portions are capable of producing negligible lesions that, over extended periods of time, can merge into large chronic injuries that result in clinical signs of liver failure (Tokarnia \& Döbereiner 1984, Lucena et al. 2010). Morbidity in outbreaks of Senecio spp. has varied from 4.92-58.6\% (mean of 17\%), and lethality is near 100\% (Barros 2016).

Two clinical courses are observed as follows: 1) a chronic course in which death is preceded by weight loss and intermittent diarrhea over several weeks or months (e.g., winter ingestion followed by death in the following winter) and 2) a clinical course that is acute (24-96 hours) and may occur in apparently healthy cattle that suddenly develop neurological signs such as aimless walking, circling, head pressing, incoordination, and blindness. Affected cattle can become oblivious to the environment or attack people or objects in their path. Nervous signs are secondary to hepatic encephalopathy and are generally premonitory of impending death (Barros 2016).

The performance of several studies of Senecio spp. poisoning in cattle in Rio Grande do Sul allows us to classify the clinical signs according to their relative frequencies. Common clinical manifestations (observed in more than $60 \%$ of cases) include a rough hair coat, anorexia, isolation from the herd, and rectal tenesmus. Moderately frequent signs (20-60\% of cases) are weight loss, diarrhea (Fig.2A), rectal prolapse (Fig.2B), neurological disorders (Fig.2C), and ascites. Uncommon manifestations (less than $20 \%$ of cases) consist of jaundice, photosensitization (Fig.2D), polydipsia, and subcutaneous dependent edema (Driemeier et al. 1991, Barros et al. 1992).

Neurological signs result from the accumulation of substances such as ammonia, short chain fatty acids, and mercaptans in the bloodstream, cerebrospinal fluid, and brain as well as changes in neurotransmitter concentrations. Typically, toxic substances are eliminated while passing through the liver. This clearance does not occur under severe and diffuse liver damage, culminating in liver failure. Consequently, these substances can reach the brain and, as false neurotransmitters, cause neurological clinical signs. Ammonia is considered the main factor involved in the pathogenesis of hepatic encephalopathy (Summers et al. 1995).

In cases of photosensitization, a more extended clinical course of intoxication (between 30-60 days) is observed (Tokarnia et al. 2012). In such cases, photosensitization is secondary (hepatogenous) and associated with tissue accumulation of phylloerythrin, a photodynamic pigment. When non-pigmented areas where phylloerythrin has been deposited are exposed to ultraviolet light, necrotizing dermatitis develops. The lesions are frequently observed in the nasal plane (Fig.2D), ears, udder and teats, periocular and vulvar skin, the skin of the dorsum, and ventral aspects of the tongue. Initially, the signs are characterized by photophobia, lacrimation, nasal secretion, and erythematous and exudative cutaneous lesions that evolve to severe crust lesions (Motta et al. 2000, Tokarnia et al. 2012, Giaretta et al. 2014a, Panziera et al. 2017). The lesion on the tongue is observed in the ventral portion (ventral diphtheric glossitis). Due to the nasal serous secretion, the affected bovine compulsively licks the secretion at the nostrils, which results in continuous exposure of the ventral aspect of the tongue to sunlight (Giaretta et al. 2014a, Panziera et al. 2017). It is important to note that other plants are also associated with hepatogenous photosensitization in livestock in Brazil, sometimes more frequently; such plants include Brachiaria decumbens and B. brizantha (Riet-Correa et al. 2011, Assumaidaee \& Mustapha 2012), Lantana spp. (Brito et al. 2004), Panicum dichotomiphlorum (Riet-Correa et al. 2009), Myoporum laetum (Raposo et al. 1998) and Enterolobium spp. (Leal et al. 2017). Thus, the epidemiological evaluation and the anatomopathological findings are important for accurate diagnosis.

Jaundice, which has been observed in a few cases, can occur due to the failure of the liver to excrete and secrete pigments, bile acids, and bile salts, with consequent tissue deposition of such substances in the tissues. Subcutaneous edema arises from hypoproteinemia and is attributed to the failure of the liver to synthesize albumin and other plasma proteins. Additionally, there are increases in portal pressure and the activation of the angiotensin aldosterone system due to the low renal perfusion resultant from ascites. The resultant increase in sodium uptake elevates blood volume and, 


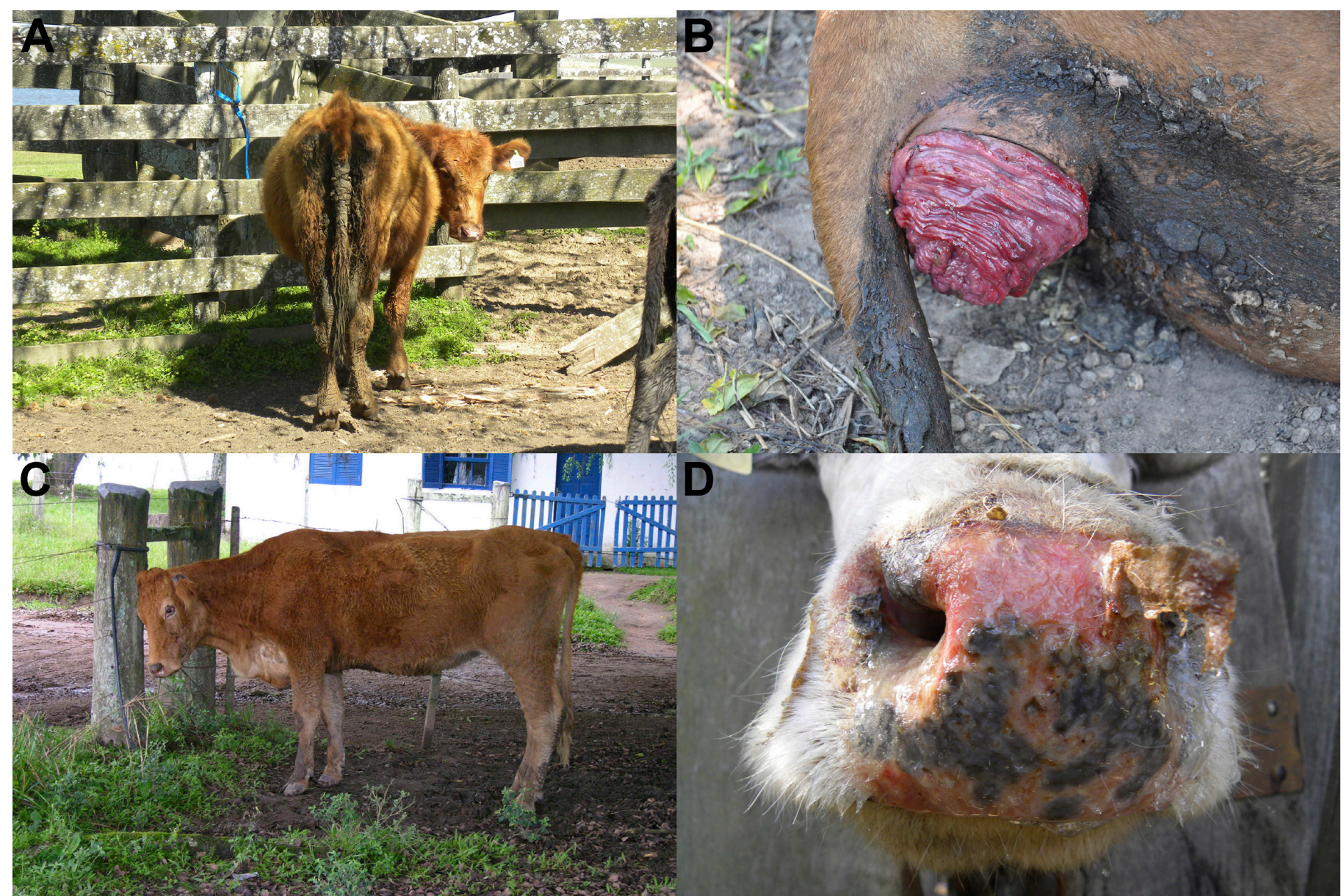

Fig.2. Clinical signs of Senecio spp. poisoning in cattle. (A) Affected steer with markedly distended abdomen (ascites), rough hair coat and dry feces adhered to the tail and perineum (evidence of diarrhea). (B) Affected steer with marked prolapse of rectum secondary to tenesmus. Dried stools adhered to the tail and perineum indicate diarrhea. (C) Heifer with head pressing. This neurological sign is secondary to liver failure (hepatic encephalopathy). (D) Cow with photodermatitis of the muzzle, secondary (hepatogenous) to liver compromise.

consequently, hydrostatic pressure (Santos et al. 2008), thus compounding the edema.

\section{PATHOLOGY AND DIAGNOSIS}

The diagnosis of intoxication by Senecio spp. in cattle is made based on epidemiological, clinical and pathological findings associated with evidence of plant consumption by animals. It is important to consider that cattle deaths may occur several months after the last ingestion of the plant. The morphological changes, predominantly hepatic changes or changes secondary to hepatic failure, are important for a definitive diagnosis (Driemeier et al. 1991, Barros et al. 1992).

Necropsy findings are those of a chronic toxic hepatopathy and are widely described (Driemeier et al. 1991, Barros et al. 1992). A significant and almost invariably gross lesion is a firm consistency of the liver. Liver size is often standard or slightly decreased. In most cases, the hepatic capsular surface is smooth and gray due to thickening of the Glisson's capsule by fibrosis (Fig.3A). Occasionally, small nodules appear on both the capsular and cut surfaces. The hepatic cut surface is crisscrossed by a fine fibrous tissue web that divides the hepatic parenchyma into irregular nodules (Fig.3B). These nodules, which are interpreted as regenerative, may be well developed or absent. Some nodules might be yellow due to fatty degeneration. In most cases, the color of the cut surface of the liver is lighter (due to fibrosis) or dark brown (Fig.3C). In some cases, red spots (necrosis and hemorrhage) are observed in the hepatic parenchyma. The gallbladder is markedly distended, often with an edematous wall and a lumen filled with inspissated bile. Edematous polyps occur in approximately $30 \%$ of cases in the mucosa of the gallbladder (Fig.3D). In almost all cases of cattle intoxication with Senecio spp., edema of the mesentery (Fig.4A) and abomasal folds (Fig.4B) is observed. The edema has a translucent and gelatinous appearance and is typically marked. A large amount (5-30 liters) of a citrine or serous fluid can be found within the abdominal cavity (ascites) (Fig.4C), primarily in adult cattle. Subcutaneous edema, mainly in the ventral portions of the mandible, neck, and brisket (dependent edema); hydrothorax (Fig.4D); hydropericardium; and portosystemic shunts are also observed, along with hemorrhages in the serosa of the abdominal viscera (Barros 2016).

Histologically, the hepatic lesions due to Senecio spp. poisoning in cattle are morphologically compatible with cirrhosis and consist of (1) hepatocyte loss, (2) hepatomegalocytosis, (3) proliferation of bile ducts, and (4) varying degrees of 


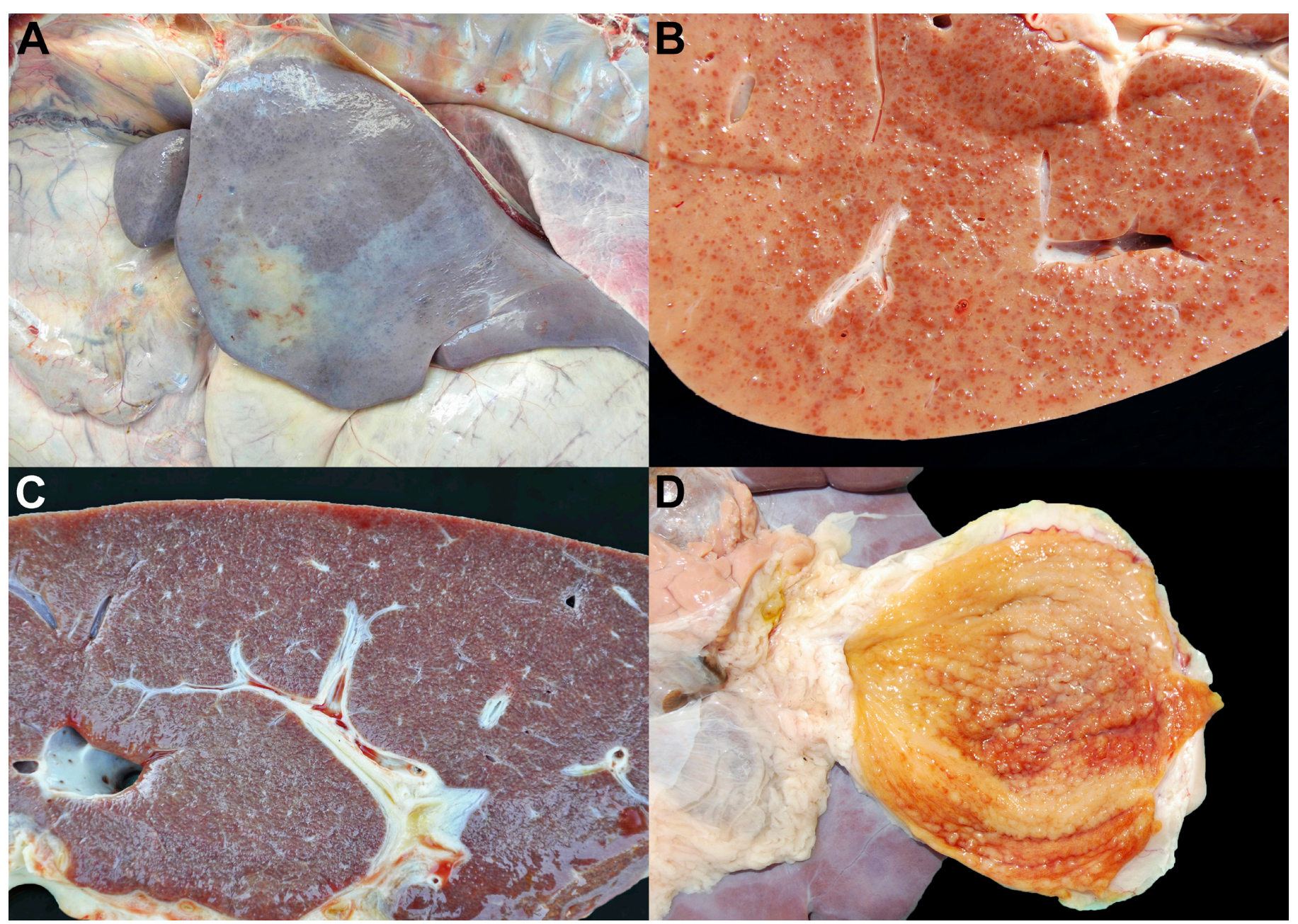

Fig.3. Necropsy findings of poisoning by Senecio spp. in cattle. (A) The hepatic capsule is thick, white slightly irregular. (B) Hepatic cut surface showing numerous small brown nodules of regeneration amidst a white background (fibrosis). (C) Hepatic cut surface showing another macroscopic pattern of liver injury caused by Senecio spp. In this case, there is a predominant brown parenchyma crisscrossed by a network of fine white strands (fibrosis). (D) Gallbladder; multiple edematous polyps are observed in the mucosa.

fibrosis (Fig.5A) (Driemeier et al. 1991, Barros et al. 1992). Hepatic fibrosis is typically of the dissecting type and causes disorganization in the normal architecture of the hepatic lobe. Frequently are observed groups of hepatocytes (regenerative nodules) often displaying vacuolar degeneration, and surrounded by a thin layer of connective tissue (Fig.5B). A disorganized proliferation of reticular fibers (reticulin) fibers dissects the parenchyma disrupting its normal collagen scaffold (Fig.5C). Occasionally, proliferated fibrous tissue obliterates centrilobular veins (veno-occlusive lesion) (Barros 2016). Veno-occlusive injury has been reported in cattle affected by aflatoxicosis (Pierezan et al. 2010, Pierezan et al. 2012) and in cases of Senecio spp. poisoning in humans (McLean 1970, Stalker \& Hayes 2007). In some cases, hepatocellular necrosis and hemorrhage are apparent.

The encephalic alterations secondary to hepatic failure (hepatic encephalopathy) are characterized by varying degrees of vacuolization (status spongiosus), mainly at the junction between the gray matter and the subcortical white matter of the frontal, parietal and occipital telencephalon and the white matter of the cerebellar peduncles (Barros 2016) (Fig.5D).
In more severe cases, vacuolization can also be observed in the thalamus, brain stem and spinal cord (Panziera et al. 2017).

Although the morphological lesions previously described are classical for Senecio spp. intoxication in cattle, in some cases, the pattern of hepatic lesions vary depending on the course of the disease. Such variation is related to the amount and distribution of fibrosis and the extents of megalocytes and biliary proliferation (Grecco et al. 2010, Panziera et al. 2017).

Spontaneous subacute cases of intoxication are uncommon; when they occur, they are characterized by the predominance of degenerative and necrotic lesions associated with a milder proliferation of ductal epithelium and fibrous connective tissue (Tokarnia \& Döbereiner 1984, Panziera et al. 2017). It is extremely important to recognize the different patterns caused by the ingestion of PAs, as the occurrence of uncommonly observed gross lesions might hinder the initial diagnosis of intoxication (Panziera et al. 2017).

The determination of the serum activity of gamma-glutamyltransferase (GGT) represents the best biochemical diagnostic parameter to identify the poisoning of cattle with Senecio spp. (Lopes et al. 1994). GGT is an enzyme 


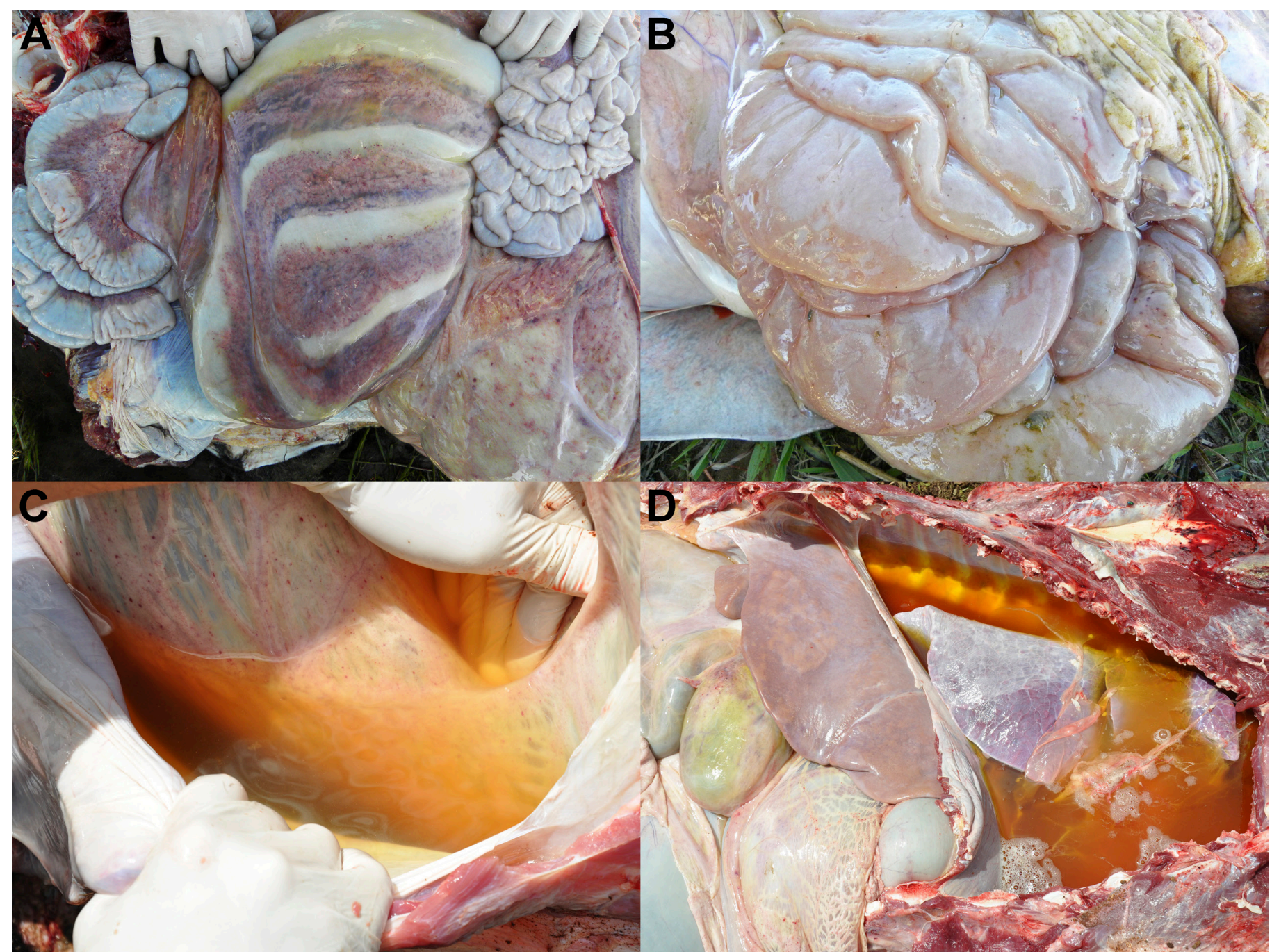

Fig.4. Necropsy findings of poisoning by Senecio spp. in cattle. (A) Marked edema of the mesentery. (B) Translucent edema markedly distends the abomasal folds. (C) Accumulation of citrine fluid in the abdominal cavity (ascites). (D) Marked accumulation of citrine fluid in the thoracic cavity (hydrothorax). The white material floating in the liquid are fibrin flakes. Furthermore, the gallbladder in this image is markedly distended.

originating from the membranes of the canaliculi and bile ducts. An increase in its serum activity is exclusively related to intra- and extra-hepatic cholestasis and the proliferation of bile ducts. This enzyme is typically restricted to the smooth endoplasmic reticulum, where the mixed oxidase system is active. This system activates the pyrrolizidine alkaloids, causing hepatocyte damage and serum GGT release (Santos et al. 2008). However, hepatic function tests are unreliable in detecting subclinical and even clinical cases of intoxication (Panziera et al. 2017) since hepatic function can be normal during this stage (Barros et al. 2007). Thus, in an outbreak of intoxication by Senecio spp. in cattle, a liver biopsy is indicated for identifying cattle with hepatic lesions, with or without clinical signs, since hepatic lesions in this intoxication are diffuse and biopsy guidance is not required. The point of choice for the introduction of the biopsy needle is the 11th right intercostal space, approximately $20 \mathrm{~cm}$ below the dorsal line, at the intersection of an imaginary line between the external tuberosity of the ileum and the scapula and another line perpendicular to the 11th intercostal space.
This site corresponds to the topographic position of the right lobe of the liver. Liver biopsy is a valuable, highly specific tool, and its application can either replace liver function tests or be applied concomitantly. Liver biopsy has almost no adverse effects and can be used to obtain epidemiological data since it allows for the estimation of the true extent of an outbreak of intoxication with Senecio spp. (Barros et al. 2007).

\section{CONTROL AND PROPHYLAXIS}

Senecio spp. poisoning in cattle can cause irreversible chronic hepatotoxic disease; there is no specific or symptomatic treatment available that can allow the recovery of affected cattle (Riet-Correa \& Méndez 2007). Thus, control and prevention methods are critical to avoid cattle intoxication with Senecio spp., and adequate management practices for areas invaded by the plant have been recommended. In Brazil, as in other parts of the world, biological and chemical methods are used to eliminate or reduce the development of the weed. Biological methods include the use of sheep 


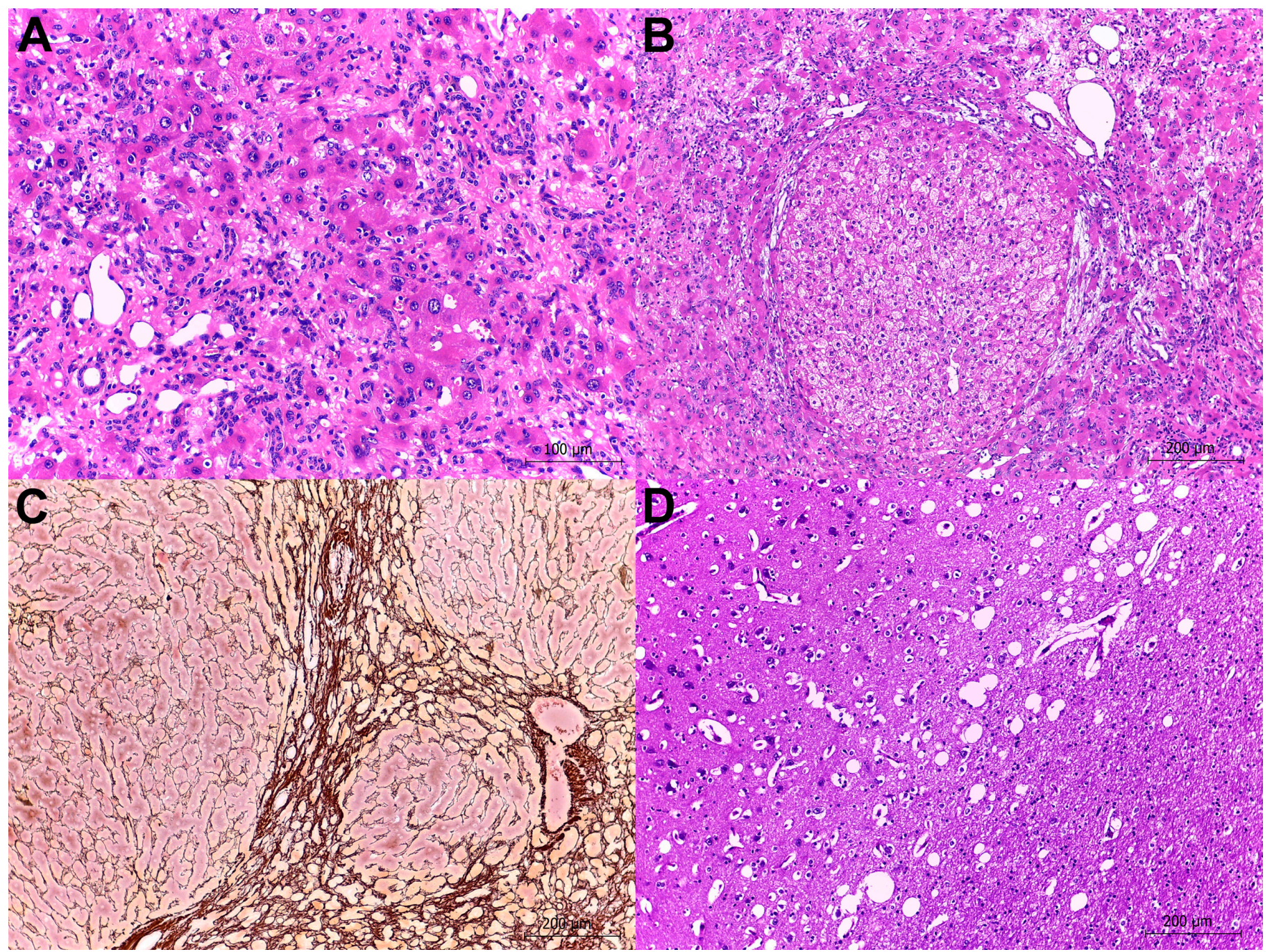

Fig.5. Histopathology of the liver and brain in Senecio spp. poisoning of cattle. (A) Most of the liver parenchyma is replaced (hepatocellular loss) by fibrosis and marked bile duct hyperplasia. The remaining hepatocytes have large nuclei and abundant eosinophilic cytoplasm (megalocytosis). HE, obj.20x. (B) Liver, groups of hepatocytes (regenerative nodules) with vacuolar degeneration are surrounded by a thin layer of connective tissue. HE, obj.10x. (C) Liver, a disorganized proliferation of reticular fibers dissects the parenchyma disrupting its normal scaffold. Gordon and Sweet's silver stain, obj.10x. (D) Telencephalon; vacuolation of the white matter is observed at the junction with the cortical grey matter. HE, obj.10x.

and (less commonly) insects, and chemical methods consist of the application of various herbicides (Coombs et al. 1991, McEvoy et al. 1991, Olson \& Lacey 1994, Jacobs \& Sing 2009, Bandarra et al. 2012). In addition, it is recommended that an adequate supply of good quality pasture proportional to animal stocking be maintained, especially during critical periods, such as the winter and the period in which Senecio spp. have higher PA contents (Karam et al. 2004, Riet-Correa \& Méndez 2007, Tokarnia et al. 2012).

Sheep grazing represents the most efficient method of biological control of Senecio spp. (Barros et al. 1987a, Driemeier et al. 1991, Barros et al. 1992, Olson \& Lacey 1994, Soares et al. 2000, Jacobs \& Sing 2009, Bandarra et al. 2012), as sheep will avidly consume Senecio spp. and thus prevent cattle intoxication. Senecio intoxication typically occurs in pastures where there are no sheep. Rates of 0.43 ovine/hectare (Soares et al. 2000) or 3.0 sheep/hectare (Bandarra et al. 2012) have been found effective for Senecio spp. control. It is estimated that cattle are 30-40 times more susceptible than are sheep and goats to the effects of PAs. The difference appears to be related to the ability of the smaller ruminants to detoxify PAs in the liver, likely a result of the diet consumed prior to domestication. In addition, sheep and goats are less selective in food intake and have thus developed greater resistance to toxins (Radostits et al. 2007, Santos et al. 2008). The resistance of sheep can also be attributed to the greater number of microorganisms in the rumen of sheep relative to cattle, allowing the more efficient inactivation of PAs by sheep (Karam et al. 2011). However, the use of sheep on pastures severely invaded by Senecio spp. for prolonged periods of time might lead to intoxication (Ilha et al. 2001, Grecco et al. 2011, Giaretta et al. 2014b).

The use of insects represents an alternative method for Senecio control (Coombs et al. 1991, McEvoy et al. 1991, Jacobs \& Sing 2009, Karam et al. 2011). The effectiveness of this method was demonstrated in a control study of 
S. jacobaea in the United States after the introduction of three insect species: Tyria jacobaeae (Lepidoptera: Arctiidae), Longitarsus jacobaeae (Coleoptera: Chrysomelidae), and Hylemya seneciella (Diptera: Anthomiidae) (McEvoy et al. 1991). In Brazil, Phaedon confinis is potentially useful for the biological control of S. brasiliensis (Mendes et al. 2005).

To control the Senecio population, practices that cause the soil to become devoid of other vegetation should be avoided (Karam \& Jarenkow 2011). Mowing can be performed before flowering, e.g., before the production and dispersal of seeds (Jacobs \& Sing 2009, Karam et al. 2011). This practice should be repeated when the sprouts reach $10-15 \mathrm{~cm}$ in height to deplete the plant's nutritional reserves and cause its disappearance. Areas with sprouts can be grazed with sheep. This method has been successfully adopted by some farmers who reported clearing the field during the transition of Senecio spp. from the vegetative to the reproductive stage, shortly before flowering, and that this practice reduced plant size by approximately $90 \%$ (Karam et al. 2011)

Chemical control has been used for species that have vegetative propagation capacity; however, with Senecio spp., chemical control should be performed only as an auxiliary method within integrated management (Jacobs \& Sing 2009). For S. madagascariensis, localized applications of low-residual post-emergent herbicides are recommended at the stage when the plants exhibit five leaves; at this stage, the minimum dose is effective, and application costs can be minimized. The herbicide does not act on the seeds. Both mechanical and chemical control should be completed during the winter if climatic conditions do not anticipate flowering. S. madagascariensis goes through several blooming periods within one year, and mechanical control has proven inefficient (Karam et al. 2011). Formulations of amine, low volatile ester forms of 2,4-D or 2,4-D emulsions are effective when applied in a proportion equivalent of one kilogram of acid per 0.4 hectares (Jacobs \& Sing 2009, Bandarra et al. 2012).

The practice of making hay or silage from areas invaded by Senecio spp. should be discouraged. The desiccation of the plant makes it more difficult for cattle to avoid it and can increase the plant's palatability (Karam et al. 2011).

Acknowledgments.- The authors thank the Conselho Nacional de Desenvolvimento Científico e Tecnológico (CNPq) and Coordenação de Aperfeiçoamento de Pessoal de Nível Superior (CAPES) for supporting this study. The author Claudio S.L. Barros is funded by a fellowship from Fundect/CAPES.

\section{REFERENCES}

Assumaidaee A.A.M. \& Mustapha N.M. 2012. Toxicity of signal grass (Brachiaria decumbens): a review article. J. Adv. Res. 2:18-39.

Bandarra P.M., Oliveira L.G., Dalto A.C., Boabaid F.M., Juffo G., Riet-Correa F., Driemeier D. \& Cruz C.E.F. 2012. Sheep production as a Senecio spp. control tool. Pesq. Vet. Bras. 32(10):1017-1022. <http://dx.doi.org/10.1590/ S0100-736X2012001000013>

Barros C.S.L. 2016. Tóxicos exógenos com ação sobre o fígado, p.249-261. In: Santos R.L. \& Alessi A.C. (Eds), Patologia Veterinária, 2 $2^{\mathrm{a}}$ ed. Roca, São Paulo.

Barros C.L.S., Metzdorf L.L. \& Peixoto P.V. 1987a. Ocorrência de surtos de intoxicação por Senecio spp. (Compositae) em bovinos no Rio Grande do Sul. Pesq. Vet. Bras. 7(1):101-107.
Barros C.S.L., Castilhos L.M. \& Santos M.N. 1987b. Liver biopsy in ragwort poisoning. Vet. Rec.121(16):382. <http://dx.doi.org/10.1136/vr.121.16.382-a> <PMid:3424596>

Barros C.S.L., Driemeier D., Pilati C., Barros S.S. \& Castilhos L.M. 1992. Senecio spp. poisoning in cattle in southern Brazil. Vet. Human Toxicol. 34(3):241246. <PMid:1609498>

Barros C.S.L., Castilhos L.M.L., Rissi D.R., Kommers G.D. \& Rech R.R. 2007. Biópsia hepática no diagnóstico da intoxicação por Senecio brasiliensis (Asteraceae) em bovinos. Pesq. Vet. Bras. 27(1):53-60. <http://dx.doi. org/10.1590/S0100-736X2007000100010>

Basile J.R., Diniz J.M.F., Okano W., Cirio S.M. \& Leite L.C. 2005. Intoxicação por Senecio spp. (Compositae) em bovinos no Sul do Brasil. Acta Scient. Vet. 33(1):63-68.

Brito M.F., Tokarnia C.H. \& Döbereiner J. 2004. A toxidez de diversas lantanas para bovinos e ovinos no Brasil. Pesq. Vet. Bras. 24(3):153-159. <http:// dx.doi.org/10.1590/S0100-736X2004000300007>

Bull L.B. 1955. The histological evidence op liver damage from pyrrolizidine alkaloids: megalocytosis of the liver and inlusion bodies. Aust. Vet. J. 31(2):33-40. <http://dx.doi.org/10.1111/j.1751-0813.1955.tb05488.x>

Cabrera A.L. 1957. El genero Senecio (Compositae) en Brasil, Paraguay y Uruguay. Arch. Jard. Bot. Rio de Janeiro 15:163-264.

Coombs E.M., Bedell T.E. \& McEvoy P.B. 1991. Tansy ragwort (Senecio jacobaea): importance, distribution and control in Oregon, p.419-428. In: James L.F., Evans J.O., Ralphs M.H. \& Child R.D. (Eds), Noxious Range Weeds. Westview Press, San Francisco.

Cruz C.E.F., Karam F.C., Dalto A.C., Pavarini S.P., Bandarra P.M. \& Driemeier D. 2010. Fireweed (Senecio madagascariensis) poisoning in cattle. Pesq. Vet. Bras. 30(1):10-12. <http://dx.doi.org/10.1590/S0100-736X2010000100002>

Driemeier D. \& Barros C.S.L. 1992. Intoxicação experimental por Senecio oxyphyllus (Compositae) em bovinos. Pesq. Vet. Bras. 12(1/2):33-42.

Driemeier D., Barros C.S.L. \& Pilati C. 1991. Seneciose em bovinos. Hora Vet. 10:23-30.

Giaretta P.R., Panziera W., Galiza G.J.A., Brum J.S., Bianchi R.M., Hammerschmitt M.E., Bazzi T. \& Barros C.S.L. 2014a. Seneciosis in cattle associated with photosensitization. Pesq. Vet. Bras. 34(5):427-432. <http://dx.doi. org/10.1590/S0100-736X2014000500007>

Giaretta P.R., Panziera W., Hammerschmitt M.E., Bianchi R.M., Galiza G.J.N., Wiethan I.S., Bazzi T. \& Barros C.S.L. 2014b. Clinical and pathological aspects of chronic Senecio spp. poisoning in sheep. Pesq. Vet. Bras. 34(10):967-973. <http://dx.doi.org/10.1590/S0100-736X2014001000008>

Grecco F.B., Schild A.L., Soares M.P., Marcolongo-Pereira C., Estima-Silva P. \& Sallis E.S.V. 2010. Aspectos epidemiológicos e padrões de lesões hepáticas em 35 surtos de intoxicação por Senecio spp. em bovinos no sul do Rio Grande do Sul. Pesq. Vet. Bras. 30(5):389-397. <http://dx.doi.org/10.1590/ S0100-736X2010000500003>

Grecco F.B., Estima-Silva P., Marcolongo-Pereira C., Soares M.P., Collares G. \& Schild A.L. 2011. Seneciose crônica em ovinos no sul do Rio Grande do Sul. Pesq. Vet. Bras. 31(4):326-330. <http://dx.doi.org/10.1590/S0100736X2011000400009>

Hirschmann G.S., Ferro E.A., Franco L., Recalde L. \& Theoduloz C. 1987. Pyrrolizidine alkaloids from Senecio brasiliensis populations. J. Natural Products 50(4):770-772. <http://dx.doi.org/10.1021/np50052a042>

Ilha M.R., Loretti A.P., Barros S.S. \& Barros C.S.L. 2001. Intoxicação espontânea por Senecio brasiliensis (Asteraceae) em ovinos no Rio Grande do Sul. Pesq. Vet. Bras. 21(3):123-138. <http://dx.doi.org/10.1590/S0100736X2001000300005>

Jacobs J. \& Sing S. 2009. Ecology and management of tansy ragwort (Senecio jacobaea L.). NRCS Montana Technical Notes-Invasive Species-MT-24, Department of Agriculture, Natural Resources and Conservation Service, Bozeman, MT. 13p. 
Johnson A.E., Molyneux R.J. \& Merrill G.B. 1985. Chemistry of toxic range plants: variation in pyrrolizidine alkaloid contente of Senecio, Amsinckia, and Crotalaria species. J. Agric. Food Chem. 33(1):50-55. <http://dx.doi. org/10.1021/jf00061a015>

Karam F.C., Schild A.L. \& Mello J.R.B. 2011. Intoxicação por Senecio spp. em bovinos no Rio Grande do Sul: condições ambientais favoráveis e medidas de controle. Pesq. Vet. Bras. 31(7):603-609. <http://dx.doi.org/10.1590/ S0100-736X2011000700010>

Karam F.S.C. \& Jarenkow J.A. 2011. Phenology of Senecio spp. and vegetation cover in the state of Rio Grande do Sul, Brazil, p.158-162. In: Riet-Correa F., Pfister J., Schild A.L. \& Wierenga T. (Eds), Poisoning by Plants, Mycotoxins and Related Toxins. CAB International, Wallingford, UK. <http://dx.doi.or $\mathrm{g} / 10.1079 / 9781845938338.0158>$.

Karam F.S.C., Méndez M.C., Jarenkow J.A. \& Riet-Correa F. 2002. Fenologia de quatro espécies tóxicas de Senecio (Asteraceae) na região Sul do Rio Grande do Sul. Pesq. Vet. Bras. 22(1):33-39. <http://dx.doi.org/10.1590/ S0100-736X2002000100007>

Karam F.S.C., Soares M.P., Haraguchi M., Riet-Correa F., Méndez M.C. \& Jarenkow J.A. 2004. Aspectos epidemiológicos da seneciose na região sul do Rio Grande do Sul. Pesq. Vet. Bras. 24(4):191-198. <http://dx.doi. org/10.1590/S0100-736X2004000400004>

Kellerman T.S., Coetzer J.A.W., Naudé T.W. \& Botha C.J. 2005. Hepatoxicosis without photosensitivity, p.3-24. In: Ibid. (Eds), Plant poisonings and Mycotoxicoses of Livestock in Southern Africa. 2nd ed. University of Oxford, Oxford, UK.

Kissmann K.G. \& Groth D. 2000. Senecio L., p.402-407. In: Ibid. (Eds), Plantas Infestantes e Nocivas. Vol.2. 2ª ed. BASF, São Paulo.

Krebs H.C., Carl T. \& Habermehl G.G. 1996. Pyrrolizidine alkaloid composition in six Brazilian Senecio species. Phytochemistry 43(6):1227-1229.<http:// dx.doi.org/10.1016/S0031-9422(96)00445-1>

Leal P.V., Pupin R.C., Lima S.C., Melo G.K., Araújo M.A., Gomes D.C., Barros C.S. \& Lemos R.A. 2017. Ingestion of the pods of Enterolobium contortisiliquum causes hepatogenous photosensitization in cattle. Toxicon 131:6-10. <http://dx.doi.org/10.1016/j.toxicon.2017.03.009> <PMid:28300579>

Liddell J.R., Stermitz F.R. \& Barros C.S.L. 1992. Pyrrolizidine alkaloids from Senecio oxyphyllus, a Brazilian poisonous plant. Biochem. Syst. Ecol. 20(4):393. <http://dx.doi.org/10.1016/0305-1978(92)90052-F>

Lopes S.T.A., Fan L.C.R., Pilati C. \& Luchese M. 1994. Perfil sorológico de equinos intoxicados experimentalmente por Senecio brasiliensis (Compositae), parte I DHL, AST, FAZ e $\gamma$ GT. Ciência Rural 24(1):91-95. <http://dx.doi. org/10.1590/S0103-84781994000100019>

Lorenzi H. 2008. Plantas Daninhas do Brasil: terrestres, aquáticas, parasitas e tóxicas. $4^{a}$ ed. Instituto Plantarum de Estudos da Flora, São Paulo, p.158.

Lucena R.B., Rissi D.R., Maia L.A., Flores M.M., Dantas A.F.A., Nobre V.M.T., RietCorrea F. \& Barros C.S.L. 2010. Intoxicação por alcaloides pirrolizidínicos em ruminantes e equinos no Brasil. Pesq. Vet. Bras. 30(5):447-452. <http:// dx.doi.org/10.1590/S0100-736X2010000500013>

Matos F.J.A., Lorenzi H., Santos L.F.L., Matos M.E.O., Silva M.G.V. \& Sousa M.P. 2011. Plantas Tóxicas: Estudo de Fitotoxicologia Química de Plantas Brasileiras. Instituto Plantarum de Estudos da Flora, São Paulo. 256p.

Matzenbacher N.I. \& Schneider A.A. 2008. Nota sobre a presença de uma espécie adventícia de Senecio (Asteraceae) no Rio Grande do Sul, Brasil. Revta Bras. Biociênc. 6:111-115.

McEvoy P., Cox C. \& Coombs E. 1991. Successful biological control of ragwort, Senecio jacobaea, by introduced insects in Oregon. Ecol. Appl.1(4):430-442. <http://dx.doi.org/10.2307/1941900> <PMid:27755672>

McKenzie R.A. 2012. Poisonous forbs: non-grass-like herbs, p.249-255. In: Ibid. (Ed.), Australia's Poisonous Plants, Fungi and Cyanobacteria. Csiro Publishing, Collingwood.
McLean E.K. 1970. The toxic actions of pyrrolizidine (Senecio) alkaloids. Pharm. Rev. 22(4):429-483. <PMid:4921839>

Mendes M.M., Leite M.L., Corrêa G.H. \& Milléo J. 2005. Entomofauna associada a Senecio brasiliensis Less. (Asteraceae), e Phaedon confinis (Insecta; Coleoptera; Chrysomelidae) como possível agente controlador desta planta tóxica. Publicatio UEPG, Ciênc. Exatas Terra, Ciênc. Agrárias Eng 11(3):45-53.

Méndez M.C. \& Riet-Correa F. 1993. Intoxication by Senecio tweediei in cattle southern Brazil. Vet. Hum. Toxicol. 35(1):55. <PMid:8434457>

Méndez M.C., Riet-Correa F. \& Schild A.L. 1987. Intoxicação por Senecio spp (Compositae) em bovinos no Rio Grande do Sul. Pesq. Vet. Bras. 7(2):51-56.

Méndez M.C., Riet-Correa F., Schild A.L. \& Martz W. 1990. Intoxicação experimental por cinco espécies de Senecio em bovinos e aves. Pesq. Vet. Bras. 10(3/4):63-69.

Molyneux R.J., Gardner D.L., Colegate S.M. \& Edgar J.A. 2011. Pyrrolizidine alkaloid toxicity in livestock: a paradigm for human poisoning? Food Additives and Contaminants 28(3):293-307. <http://dx.doi.org/10.108 0/19440049.2010.547519><PMid:21360375>

Motidome M. \& Ferreira P.C. 1966. Alcalóides do Senecio brasiliensis Less Revta Fac. Farm. Bioquím. USP 4:38-44.

Motta A.C., Rivero G.R., Schild A.L., Riet-Correa F., Méndez M.C. \& Ferreira J.L. 2000. Fotossensibilização hepatógena em bovinos no Sul do Rio Grande do Sul. Ciência Rural 30(1):143-149. <http://dx.doi.org/10.1590/S010384782000000100023>

Olson B.E. \& Lacey J.R. 1994. Sheep: a method for controlling rangeland weeds. Sheep Goat Res. J. 105-112.

Panziera W., Gonçalves M.A., Oliveira L.G.S., Lorenzett M.P., Reis M., Hammerschmitt M.E., Pavarini S.P. \& Driemeier D. 2017. Intoxicação por Senecio brasiliensis em bezerros: padrão e evolução de lesões hepáticas. Pesq. Vet. Bras. 37(7):8-16. <http://dx.doi.org/10.1590/ s0100-736x2017000100002>

Pavarini D.P., Pavarini S.P., Niehues M. \& Lopes N.P. 2012. Exogenous influences on plant secondary metabolite levels. Anim. Feed Sci. Technol. 176(1/4):516. <http://dx.doi.org/10.1016/j.anifeedsci.2012.07.002>

Pedroso P.M.O., Pescador C.A., Oliveira E.C., Sonne L., Bandarra P.M., Raymundo D.L. \& Driemeier D. 2007. Intoxicações naturais por plantas em ruminantes diagnosticadas no Setor de Patologia Veterinária da UFRGS no período de 1996-2005. Acta Scient. Vet. 35(2):213-218.

Pierezan F., Oliveira Filho J.C., Carmo P.M., Lucena R.B., Rissi D.R., Togni M. \& Barros C.S.L. 2010. Surto de aflatoxicose em bezerros no Rio Grande do Sul. Pesq. Vet. Bras. 30(5):418-422. <http://dx.doi.org/10.1590/S0100736X2010000500008>

Pierezan F., Oliveira-Filho J.C., Carmo P.M., Aires A.R., Leal M.L.R., Souza T.M., Mallmann C.A. \& Barros C.S.L. 2012. Intoxicação experimental por aflatoxina em bezerros. Pesq. Vet. Bras. 32(7):607-618. <http://dx.doi org/10.1590/S0100-736X2012000700004>

Prakash A.S., Pereira T.N., Reilly P.E.B. \& Seawright A.A. 1999. Pyrrolizidine alkaloids in human diet. Mutat. Res. Genet. Toxicol. Environ. Mutagen. 443(1/2):53-67. <http://dx.doi.org/10.1016/S1383-5742(99)00010-1> $<$ PMid:10415431>

Preliasco M., Gardner D., Moraes J., Gonzalez A.C., Uriarte G. \& Rivero R. 2017. Senecio grisebachii Baker: Pyrrolizidine alkaloids and experimental poisoning in calves. Toxicon 133:68-73. <http://dx.doi.org/10.1016/j. toxicon.2017.05.004><PMid:28478055>

Radostits O.M., Gay C.C., Hinchcliff K.W. \& Constable P.D. 2007. Diseases associated with toxins in plants, fungi, cyanobacteria, plant-associated bacteria, and venoms in ticks and vertebrate animals, p.1850-1920. In: Ibid (Eds), Veterinary Medicine. 10th ed. Saunders Elsevier, Philadelphia. 2156p. 
Raposo J.B., Méndez M.C., Riet-Correa F. \& Andrade G.B. 1998. Experimental intoxication by Myoporum laetum in sheep. Vet. Human Toxicol. 40(3):132135. <PMid:9610488>

Riet-Correa F. \& Medeiros R.M.T. 2001. Intoxicações por plantas em ruminantes no Brasil e no Uruguai: importância econômica, controle e riscos para a saúde pública. Pesq. Vet. Bras. 21(1):38-42.<http://dx.doi.org/10.1590/ S0100-736X2001000100008>

Riet-Correa F. \& Méndez M.C. 2007. Intoxicação por plantas e micotoxinas, p.99-221. In: Riet-Correa F., Schild A.L., Lemos R.A.A. \& Borges J.R. (Eds), Doenças de Ruminantes e Equídeos. Vol.2. 3aㅡ ed. Pallotti, Santa Maria.

Riet-Correa F., Haraguchi M., Dantas A.F., Burakovas R.G., Yokosuka A., Mimaki Y., Medeiros R.M.T. \& Matos P.F. 2009. Sheep poisoning by Panicum dichotomiflorum in northeastern Brazil. Pesq. Vet. Bras. 29(1):94-98. <http://dx.doi.org/10.1590/S0100-736X2009000100015>

Riet-Correa B., Castro M.B., Lemos R.A.A., Riet-Correa G., Mustafa V. \& RietCorrea F. 2011. Brachiaria spp. poisoning of ruminants in Brazil. Pesq. Vet. Bras. 31(3):3-7. <http://dx.doi.org/10.1590/S0100-736X2011000300001>

Rissi D.R., Rech R.R., Pierezan F., Gabriel A.L., Trost M.E., Brum J.S., Kommers G.D. \& Barros C.S.L. 2007. Intoxicações por plantas e micotoxinas associadas a plantas em bovinos no Rio Grande do Sul: 461 casos. Pesq. Vet. Bras. 27(7):261-268. <http://dx.doi.org/10.1590/S0100-736X2007000700002>

Roux J., Wieczorek A.M., Ramadan M.M. \& Tran C.T. 2006. Resolving the native provenance of invasive fireweed (Senecio madagascariensis Poir.) in the Hawaiian Islands as inferred from phylogenetic analysis. Diversity and Distributions 12(6):694-702. <http://dx.doi.org/10.1111/j.1472-4642.2006.00271.x>

Sandini T.M., Udo M.S.B. \& Spinosa H.D.S. 2013. Senecio brasiliensis e alcaloides pirrolizidínicos: toxicidade em animais e na saúde humana. Biotemas 26(2):83-92. <http://dx.doi.org/10.5007/2175-7925.2013v26n2p83>

Santos J.C.A., Riet-Correa F., Simões S.V.D. \& Barros C.S.L. 2008. Patogênese, sinais clínicos e patologia das doenças causadas por plantas hepatotóxicas em ruminantes e equinos no Brasil. Pesq. Vet. Bras. 28(1):1-14. <http:// dx.doi.org/10.1590/S0100-736X2008000100001>

Scott L.J., Congdon C. \& Playford J. 1998. Molecular evidence that fireweed (Senecio madagascariensis, Asteraceae) is of South African origin. Plant Syst. Evol. 213(3/4):251-257. <http://dx.doi.org/10.1007/BF00985204>

Seawright A.A., Kelly W.R., Hrdlicka J., McMahon P., Mattocks A.R. \& Jukes R. 1991. Pyrrolizidine alkaloids in cattle due to Senecio species in Australia. Vet. Rec. 129(9):198-199. <PMid:1957473>
Silva C.M., Bolzan A.A. \& Heinzmann B.M. 2006. Alcalóides pirrolizidínicos em espécies do gênero Senecio. Quím. Nova 29(5):1047-1053. <http:// dx.doi.org/10.1590/S0100-40422006000500026>

Soares M.P., Riet-Correa F., Méndez M.C., Rosa F.G. \& Carreira E.G. 2000. Controle biológico de Senecio spp. com pastoreio de ovinos. Anais II Reunión Argentina de Patologia Veterinária, Facultad de Ciências Veterinárias, Universidad Nacional Del Nordeste, Corrientes, Argentina, p.79. (Resumo)

Sperl W., Stuppner H., Gassner I., Judmaier W., Dietze O. \& Vogel W. 1995. Reversible hepatic veno-occlusive disease in an infant after consumption of pyrrolizidine-containing herbal tea. Eur. J. Pediatr. 154(2):112-116. <http://dx.doi.org/10.1007/BF01991912> <PMid:7720737>

Stalker M.J. \& Hayes M.A. 2007. Liver and biliary system, p.297-388. In. Maxie M.G. (Ed.), Jubb, Kennedy and Palmer's Pathology of Domestic Animals. Vol.2. 5th ed. Saunders Elsevier, Philadelphia.

Stigger A.L., Estima-Silva P., Fiss L., Coelho A.C.B., Santos B.L., Gardner D.R., Marcolongo-Pereira C. \& Schild A.L. 2014. Senecio madagascariensis Poir. (Asteraceae): uma nova causa de seneciose em bovinos no Sul do Rio Grande do Sul. Pesq. Vet. Bras. 34(9):851-855. <http://dx.doi.org/10.1590/ S0100-736X2014000900008>

Summers B.A., Cummings J.F. \& De Lahunta A. 1995. Degenerative diseases of the central nervous system, p.208-214. In: Ibid. (Eds), Veterinary Neuropathology. Mosby, St Louis.

Tokarnia C.H. \& Döbereiner J. 1984. Intoxicação experimental por Senecio brasiliensis (Compositae) em bovinos. Pesq. Vet. Bras. 4(2):39-65.

Tokarnia C.H., Gava A., Peixoto P.V., Stolf L., Consorte L.B. \& Döbereiner J. 1990. Intoxicaçäo experimental por Senecio desiderabilis (Compositae) em bovinos. Pesq. Vet. Bras. 10(1/2):35-42.

Tokarnia C.H., Brito M.F., Barbosa J.D., Peixoto P.V. \& Döbereiner J. 2012. Senecio spp., p.177-191. In: Ibid. (Eds), Plantas Tóxicas do Brasil para Animais de Produção. 2 ${ }^{\mathrm{a}}$ ed. Helianthus, Rio de Janeiro.

Torres M.B.A. \& Coelho K.I.R. 2008. Experimental poisoning by Senecio brasiliensis in calves: quantitative and semi-quantitative study on changes in the hepatic extracellular matrix and sinusoidal cells. Pesq. Vet. Bras. 28(1):43-50. <http://dx.doi.org/10.1590/S0100-736X2008000100007>

Tsutsumi M. 2011. Current and potential distribution of Senecio madagascariensis Poir (fireweed), an invasive alien plant in Japan. Grassl. Sci. 57(3):150-157. <http://dx.doi.org/10.1111/j.1744-697X.2011.00222.x>

Villalba J. \& Fernández G. 2005. Otra flor amarilla peligrosa: Senecio madagascariensis. Tambo 150:46-48. 